\title{
Screening for Nephropathy in Diabetes Mellitus: Is Micral-Test Valid among All Diabetics?
}

\author{
Koubaa Afifa, ${ }^{1}$ Sriha Belguith Asma, ${ }^{2}$ Harzallah Nabil, ${ }^{3}$ Bellaleh Ahlem, \\ Sahtout Mounira, ${ }^{5}$ Younes Kawthar, ${ }^{1}$ Triki Sonia, ${ }^{6}$ Hellara Ilhem, ${ }^{6}$ Neffati Fadoua, \\ Najjar Fadhel, ${ }^{6}$ and Soltani Mohamed ${ }^{2}$ \\ ${ }^{1}$ Stah Jabeur Primary Health Center, Monastir Health Group, 5000 Monastir, Tunisia \\ ${ }^{2}$ Department of Preventive Medicine and Epidemiology, Faculty of Medicine, Monastir, Tunisia \\ ${ }^{3}$ Primary Health Center, Monastir Health Group, Monastir, Tunisia \\ ${ }^{4}$ Department of Pathology, Monastir, Tunisia \\ ${ }^{5}$ C2 Primary Health Center, Monastir Health Group, Monastir, Tunisia \\ ${ }^{6}$ Biochemistry Laboratory, Faculty of Pharmacy, Monastir, Tunisia
}

Correspondence should be addressed to Sriha Belguith Asma; belguith_asma@yahoo.fr

Received 20 January 2016; Accepted 27 April 2016

Academic Editor: Jens Klotsche

Copyright (C) 2016 Koubaa Afifa et al. This is an open access article distributed under the Creative Commons Attribution License, which permits unrestricted use, distribution, and reproduction in any medium, provided the original work is properly cited.

\begin{abstract}
Background. Using Micral-test (MT) for screening microalbuminuria (MA) among type 2 diabetics (T2D) is helpful. We aimed at determining prevalence of MA and at describing the MT validity. Methods. We studied 182 T2D followed up in family medicine. Two 24-hour urinary quantitative assays of MA had been used as a gold standard. Results. Prevalence of MA was 23\%, CI 95\%: 16.9-29.1. MT validity was $77 \%$ for sensitivity, $88 \%$ for negative predictive value, and 0.2 for Kappa coefficient $(p=0.001)$. Among subjects having a blood pressure $\geq 130 / 80 \mathrm{mmHg}$, having a CHT/HDL ratio $\geq 3$, being a T2D for more than 5 years, and being women, negative predictive values were, respectively, $91 \%, 89 \%, 95 \%$, and $91 \%$. The area under the ROC curve was 0.81 in men $(p=0.008)$ and 0.80 when diabetes duration exceeds 5 years $(p=0.001)$. The MA value at $100 \% \mathrm{Sp}$ for MT was $35 \mathrm{mg} / \mathrm{L}$. Conclusion. The use of MT in primary healthcare for yearly screening for MA in T2D must be accentuated especially when diabetes duration exceeds 5 years or when associated with other cardiovascular risks.
\end{abstract}

\section{Introduction}

Screening and management of early stage of diabetes are insured by the family practitioner, while Tunisian diabetics with complications are managed by specialists. Diabetic nephropathy $(\mathrm{DN})$ is the commonest cause of end-stage renal disease (ESRD) [1]. Screening for microalbuminuria (MA) is required in primary healthcare centers to prevent the progression of this serious complication [2-5]. The prevalence of DN is increasing along with the diabetes prevalence [6]. It should be detected and treated by the family doctor, at the stage of MA which is potentially reversible and associated with an increased risk of cardiovascular morbidity and mortality [7, 8]. The determination of MA by the semiquantitative method, Micral-test (MT), is a rapid screening tool. It is the easiest method, using urinary strips and a spot urine specimen. It is simple and inexpensive $[9,10]$. The aim of this study was to assess the validity of MT criteria to detect DN among subgroups of diabetics and therefore to establish prevalence of MIA in diabetics managed in primary healthcare centers.

\section{Methods}

2.1. Design. This is a cross-sectional study, conducted from January 2013 to December 2014, to screen diabetic patients for elevated urinary albumin excretion with Micral-test in general practice.

2.2. Patients. We have included type 2 diabetics (T2D) without known complications followed up in two primary healthcare centers based in Monastir ("Stah Jabeur" and "C2"). 
Patients with fever, transitory diabetes decompensation, urinary infection, hematuria, or DN managed by a specialist were excluded from the study.

2.3. Study Area. Monastir is a coastal city located in the central eastern part of Tunisia. It includes 7 primary healthcare centers. Over than 20,000 inhabitants are followed up in "Stah Jabeur" and "C2" centers. Those centers were chosen because they manage diabetics at early stage.

2.4. Methods. The participants benefited from screening using the MT, done at the primary healthcare center. For the gold standard, two quantitative assays of MA on the urine of 24 hours were performed at one-month interval, at the Biochemistry Laboratory of the University Hospital of Monastir. MA was considered pathological if urinary albumin concentration (UAC) was between 30 and $300 \mathrm{mg}$ in the urine of 24 hours. A third quantitative assay was performed in case of discordance. The MT is a semiquantitative strip test done on a urine sample in order to determinate MA. A comparative color scale is used to assess the results of MT: at a concentration of $0 \mathrm{mg} / \mathrm{L}$ of microalbumin in the urine, the strip remains white; it turns to light pink at $20 \mathrm{mg} / \mathrm{L}$, to dark pink at $50 \mathrm{mg} / \mathrm{L}$, and finally to very dark pink at more than $100 \mathrm{mg} / \mathrm{L}$. A therapeutic education session was conducted on the test's day in primary healthcare center to improve patients' participation to MT and quantitative assays. Answerable nurse received information about this study.

2.5. Parameters. The participants also benefited from multiple blood tests. The studied parameters were sociodemographic data (age, gender), information about diabetes (diabetes duration, fasting blood glucose levels, glycated hemoglobin (HbAlC)), and risk factors associated with T2D (blood pressure, total cholesterol, and HDL cholesterol (HDL-C)). Total cholesterol to HDL-C ratio was calculated; the patient was considered as being at low risk of overload if this ratio was less than 3 , at intermediate risk between 3 and 4.4, and at high risk if more than 4.5 [11]. Controlled glycemia is defined as the ADA [12]. Renal function was assessed by the measurement of glomerular filtration rate (GFR) calculated using the MDRD formula (modification of diet and renal disease). Some variables influence AUC, as was found in the literature. So we have analyzed validity criteria of MT according to demographic variables, blood pressure, $\mathrm{CH} / \mathrm{HDL}-\mathrm{C}$ ratio, and T2D duration.

2.6. Statistical Analysis. Statistical data were performed on SPSS 17.0 computer software. Sensitivity and specificity were calculated to determine the diagnostic properties of MT in predicting a UAC greater than or equal to $30 \mathrm{mg} / 24$ hours. To determine the confidence intervals for sensitivity and specificity, we used the guidelines of Gardner and Altman. The coefficient Kappa $(\kappa)$ was used to assess the concordance between the MT and the quantitative measurement of MIA. A value of $p<0.05$ was considered as the cut-off of significance. The cut-off point for $100 \%$ specificity and the equilibrium point between sensibility and specificity were determined. We assessed, according to the subgroups, diagnostic sensitivity, specificity, positive and negative predictive values, Kappa coefficient, positive likelihood ratio, and negative likelihood ratio. The ROC curves of $\mathrm{MT}$ in diurnal random urine specimen for screening of MA according to the subgroups were plotted.

\section{Results}

3.1. Description of the Study's Population. We have included 182 T2D among whom 122 were followed up in the primary healthcare center "Stah Jabeur" and 60 in "C2" center. The mean age of the patients was 61.4 years (SD: 11.9). Females represented $69.2 \%$ of the studied population ( $\operatorname{sex}$ ratio $=0.44$ ) and $62 \%$ had hypertension. The mean duration of diabetes was 8.1 years (SD: 6.4). Fasting blood glucose levels value was $<7 \mathrm{mmol} / \mathrm{L}$ in $31 \%$ of the cases and the $\mathrm{HbAlC}<7 \%$ in $30 \%$ of T2D. Blood pressure was $\geq 130 / 80 \mathrm{mmHg}$ in $66 \%$ of the studied population and $49 \%$ of the patients were obese. Mild renal impairment was present in $47.6 \%$ of diabetics. The prevalence of MA was 23\%; CI 95\% = 16.9-29.1.

3.2. Variability of Micral-Test Validity. The MT had $77 \%$ sensitivity, CI 95\%: 65.5-88.9, 46\% specificity, and a negative predictive value (NPV) of $88 \%$. The positive likelihood ratio was 1.4 and the negative likelihood ratio was 0.5 . The validity of MT was better in women (NPV $=91 \% ; \kappa=0.3 ; p=0.008)$, subjects having a blood pressure $\geq 130 / 80 \mathrm{mmHg}(\mathrm{NPV}=$ $91 \% ; \kappa=0.24 ; p=0.005)$ or a total $\mathrm{CHT} / \mathrm{HDL}$ ratio $\geq 3$ $(\mathrm{NPV}=89 \% ; \kappa=0.36 ; p=0.01)$, and patients who have had T2D for more than 5 years $(\mathrm{NPV}=95 \% ; \kappa=0.38$; $p=0.001$ ) (Table 1 ). The cut-off point for $100 \%$ specificity was $35 \mathrm{mg} / \mathrm{L}$ for all studied subgroups. The equilibrium point between sensitivity and specificity was $10 \mathrm{mg} / \mathrm{L}$ (Table 2 ). The area under the ROC curves was 0.72 : CI 95\% $=0.581-0.863$ ( $p=0.001)$ for the entire study population. It was 0.81 in men $(p=0.008)$ and 0.80 when diabetes duration exceeds 5 years $(p=0.001)$ (Figure 1$)$.

\section{Discussion}

The highlight of this study is that it was conducted in first-line therapy for diabetes in early stage. It allowed us to determine the accuracy of the MT in the detection of MA among diabetics subgroups and to estimate MA prevalence. This subject was little discussed in the Tunisian studies contrary to world literature $[9,10,13-17]$.

Our diabetic population was characterized by a female majority, as described in the literature [18, 19]. Different distributions were found though $[20,21]$. The mean age $(61.4$ years) and the mean duration of diabetes (8.1 years (SD: 6.4)) were similar to those reported by other authors $[13,22]$. We found that $30 \%$ of diabetics had a good glycemic control, and this result matches those observed in other Arab countries (Morocco, Kuwait, and Emirates) [13, 23, 24]. The glycemic control was better in China [25]. The review of literature shows a great variability in the prevalence of MA in T2D (Table 3); this prevalence ranged from 11.5 to $58.2 \%[13,26]$. 
TABLE 1: Assessment of validity of Micral-test according to subgroups of diabetics.

\begin{tabular}{|c|c|c|c|c|c|c|c|}
\hline Cut-off value: $20 \mathrm{mg} / \mathrm{L}$ & Sensibility (\%) & Specificity (\%) & Kappa & $p$ & NPV & PLR & NLR \\
\hline Entire population & $\begin{array}{c}77.2 \\
\text { CI 95\% [65.5-88.9] }\end{array}$ & $\begin{array}{c}46.3 \\
\text { CI 95\% [32.4-60.2] }\end{array}$ & 0.2 & 0.001 & 88.4 & 27.8 & \\
\hline \multicolumn{8}{|l|}{ Gender: } \\
\hline (i) Male & $66.6 \%$ & $46.6 \%$ & 0.103 & 0.008 & $77.7 \%$ & 1.2 & 0.74 \\
\hline (ii) Female & $77 \%$ & $66 \%$ & 0.323 & 0.006 & $90.6 \%$ & 2.26 & 0.34 \\
\hline$B P \geq 130 / 80 \mathrm{mmHg}$ & $81 \%$ & $54.1 \%$ & 0.236 & 0.005 & $\mathbf{9 0 . 7} \%$ & 1.76 & 0.35 \\
\hline CHT/C-HDL ratio $\geq 3$ & $83.3 \%$ & $60.1 \%$ & 0.363 & 0.011 & $89.4 \%$ & 2.07 & 0.28 \\
\hline T2D duration $>5$ years & $91 \%$ & $60.6 \%$ & 0.378 & 0.001 & $95.2 \%$ & 2.27 & 0.15 \\
\hline
\end{tabular}

NPV: negative predictive value.

PLR: positive likelihood ratio.

NLR: negative likelihood ratio.
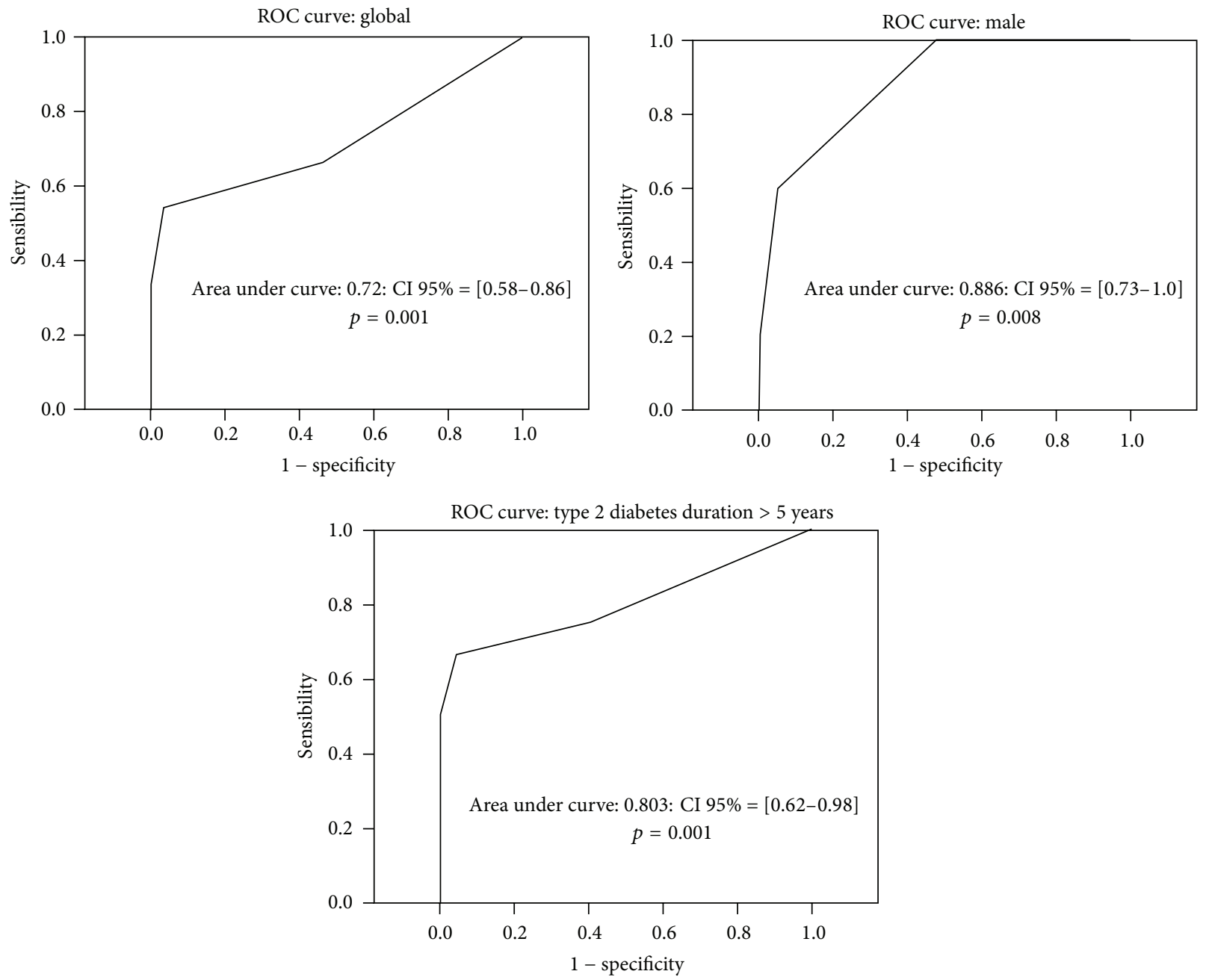

FIgURE 1: The area under the ROC curve of Micral-test (mg/L) in microalbuminuria screening.

This variation can be mainly attributed to the genetic and the ethnic dissimilarities between the studied groups [27] and to the difference in the classifications system. Among the studied population, 36 patients had MA (23\%). This finding is comparable to those obtained in the United Kingdom Prospective Diabetes Study (UKPDS) [28] and in Adler et al's study [28] and Arfa et al.'s work [29] done in Tunisian specialized departments. MA's prevalence was lower in an Argentinean study [25] and greater in Canadian and Moroccan studies $[13,30,31]$. Several methods were used for the detection of the MA. The quantitative methods include the determination of the urinary albumin concentration (UAC) 


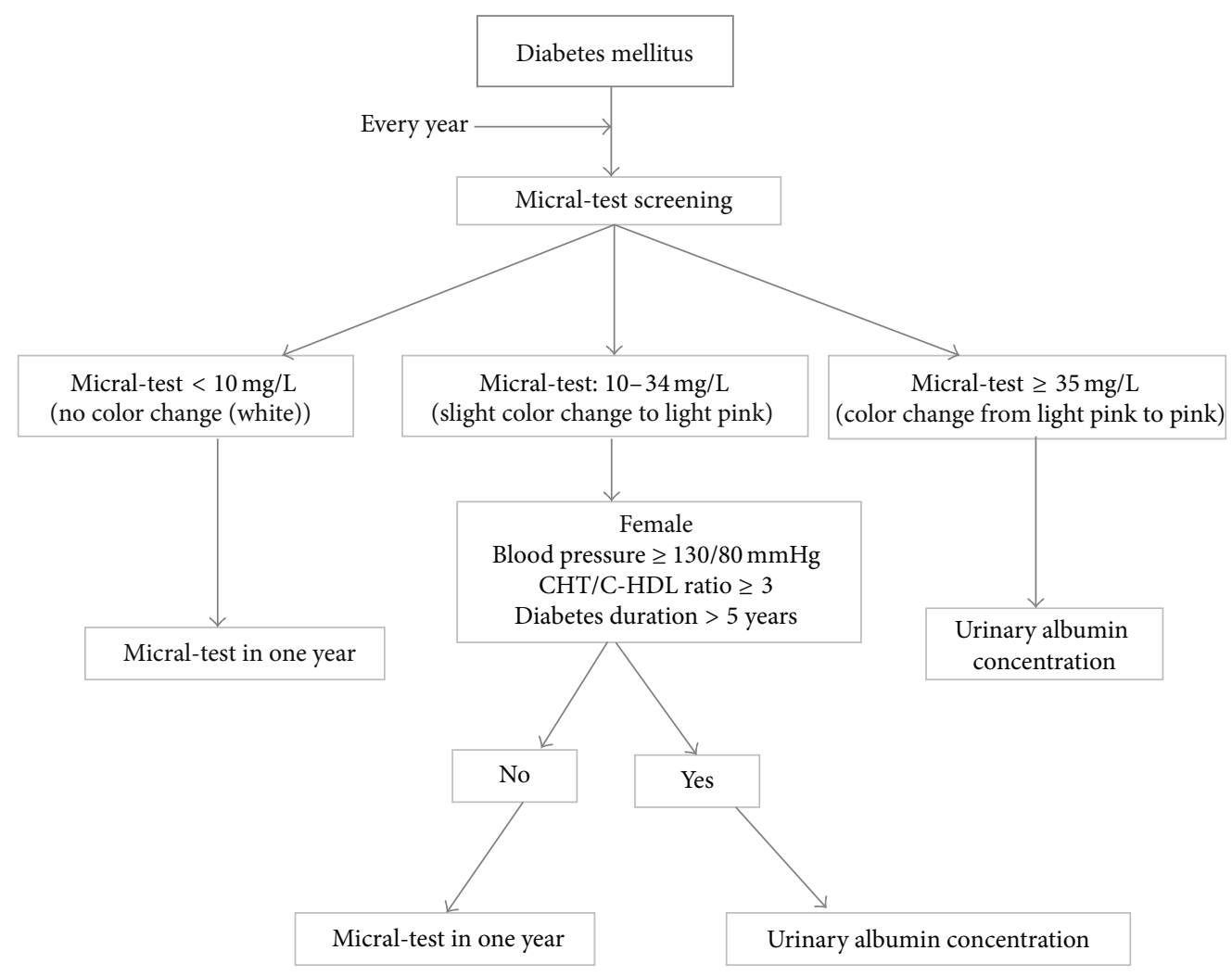

FIGURE 2: Algorithm for screening nephropathy in diabetes mellitus with Micral-test.

TABLE 2: Sensitivity and specificity among subgroups depending on the chosen point.

\begin{tabular}{ccc}
\hline & $\begin{array}{c}\text { Cut-off point for 100\% } \\
\text { specificity for MT }\end{array}$ & $\begin{array}{c}\text { Equilibrium point } \\
\text { between sensibility } \\
\text { and specificity }\end{array}$ \\
\hline Entire population & $35 \mathrm{mg} / \mathrm{L}$ & $10 \mathrm{mg} / \mathrm{L}$ \\
Sensitivity & $54.2 \%$ & $66.7 \%$ \\
Specificity & $100 \%$ & $53.6 \%$ \\
Gender: male & $35 \mathrm{mg} / \mathrm{L}$ & $10 \mathrm{mg} / \mathrm{L}$ \\
Sensitivity & $60 \%$ & $100 \%$ \\
Specificity & $100 \%$ & $52.4 \%$ \\
BP $\geq 130 / 80 \mathrm{mmHg}$ & $35 \mathrm{mg} / \mathrm{L}$ & $10 \mathrm{mg} / \mathrm{L}$ \\
Sensitivity & $52.4 \%$ & $66.7 \%$ \\
Specificity & $100 \%$ & $53.6 \%$ \\
CHT/C-HDL ratio $\geq 3$ & $35 \mathrm{mg} / \mathrm{L}$ & $10 \mathrm{mg} / \mathrm{L}$ \\
Sensitivity & $58.3 \%$ & $58.3 \%$ \\
Specificity & $100 \%$ & $57.5 \%$ \\
T2D duration $>5$ years & $35 \mathrm{mg} / \mathrm{L}$ & $10 \mathrm{mg} / \mathrm{L}$ \\
Sensitivity & $\mathbf{6 6 . 7 \%}$ & $75 \%$ \\
Specificity & $100 \%$ & $60 \%$ \\
\hline
\end{tabular}

and the urinary albumin-to-creatinine ratio (UACR) in a first morning urine sample, $24 \mathrm{~h}$ urine collection, or timed urine collection. These two methods are performed in the laboratory by radioimmunoassay, radial immunodiffusion, enzyme immunoassay (ELISA), or immunoturbidimetric means. Among semiquantitative methods, the MT has been the most used screening tool for the detection of MA in many countries [32]. This test involves the immunochromatographic principle. Initially, the labeled antibody is combined with the sample albumin. Then, during the migration, excess conjugate is retained by the immobilized human albumin. Finally, the complex spread by migration on the strip to a revelation area. A more or less intense pink color appears in the play area based on the initial concentration of albumin $[33,34]$. In different studies (Table 4), the MT precision varied from 67 to $96.7 \%$ and the specificity ranged from 46 to $96 \%$ [9, 32, 33, 35-39]. Table 5 shows a comparison between Micral-test and Multistix ${ }^{\circledR}$ commonly used for detection of $\mathrm{DN}$ in Tunisia. Our results are similar to Incerti's findings [36] for the same cut-off $(20 \mathrm{mg} / \mathrm{L})$. The MT validity was better in men $(p=0.008)$, subjects having a $\mathrm{BP} \geq 130 / 80 \mathrm{mmHg}$ $(p=0.005)$ or a cholesterol/C-HDL ratio $\geq 3(p=0.011)$, and patients who have had T2D for more than 5 years $(p=$ $0.001)$. The point for $100 \%$ specificity ( $0 \%$ false positives) was $35 \mathrm{mg} / \mathrm{L}$ among all subgroups. The equilibrium point between sensibility and specificity was $10 \mathrm{mg} / \mathrm{L}$; it was between 26 and $32 \mathrm{mg} / \mathrm{L}$ in Incerti et al.s study [36]. Several studies have shown that the MT is commonly used worldwide, that it is a good screening tool for MA [32, 33, 36, 37, 39], and that positive results should be confirmed and quantified by a reference assay $[33,36]$. Few authors have discussed the limitation of the diagnosis value of MT due to the rate of false positive [40], high costs, and the possibility of false negative 
TABLE 3: Microalbuminuria's prevalence in the literature.

\begin{tabular}{|c|c|c|c|}
\hline Study & Number of patients & MA measurement method & MA's prevalence (\%) \\
\hline Our study & 182 & $\begin{array}{l}\text { 24-hour urinary } \\
\text { UAC: } 30-300 \mathrm{mg} / \mathrm{d}\end{array}$ & $23 \%$ \\
\hline Kuwait, 2008 [23] & 440 & Micral-test & $14.2 \%$ \\
\hline Argentina, 2011 [26] & 88 & $\begin{array}{l}\text { 24-hour urinary } \\
\text { UAC: } 30-300 \mathrm{mg} / \mathrm{d}\end{array}$ & $46.2 \%$ \\
\hline Albania, 2013 [43] & 222 & $\begin{array}{c}\text { Matinal urine } \\
\text { UACR: } 30-300 \mathrm{mg} / \mathrm{g}\end{array}$ & $38.6 \%$ \\
\hline Italy, 1996 [41] & 1574 & $\begin{array}{c}\text { Night urine } \\
\text { UAC: } 20-200 \mu \mathrm{g} / \mathrm{min}\end{array}$ & $32.1 \%$ \\
\hline Tunisia, 2014 [44] & 120 & - & $27.5 \%$ \\
\hline Tunisia, 2008 [29] & 141 & $\begin{array}{l}\text { 24-hour urinary } \\
\text { UAC: } 30-300 \mathrm{mg} / \mathrm{d}\end{array}$ & $25.5 \%$ \\
\hline Morocco, 2009 [13] & 728 & $\begin{array}{l}\text { 24-hour urinary } \\
\text { UAC: } 30-300 \mathrm{mg} / \mathrm{d}\end{array}$ & $11.5 \%$ \\
\hline
\end{tabular}

UAC: urinary albumin concentration.

UACR: urinary albumin creatinine ratio.

TABLE 4: Micral-test's validity in literature.

\begin{tabular}{|c|c|c|c|c|c|}
\hline Study & Number of patients & Sensibility (\%) & Specificity (\%) & NPV (\%) & Area under curve \\
\hline Our study & 182 & 77 & 46 & 88 & 0.72 \\
\hline De Grauw et al. [35] & 401 & 67 & 93 & & 0.84 \\
\hline Incerti et al. [36] & 278 & 90 & 46 & & 0.84 \\
\hline Mogensen et al. [37] & 2228 & 96.7 & 71 & & - \\
\hline Parikh et al. [38] & 444 & 88 & 80 & & - \\
\hline Sarafidis et al. [39] & 165 & 70 & 83 & & - \\
\hline Cortés-Sanabria et al. [9] & 71 & 83 & 96 & 88 & 0.91 \\
\hline Larijani et al. [32] & 200 & 93 & 87 & 92 & \\
\hline Le Floch et al. [33] & 302 & 79 & 81 & 95 & - \\
\hline Mogensen et al. [37] & 530 & 78 & 77 & & \\
\hline
\end{tabular}

NPV: negative predictive value.

TABLE 5: Comparison of commonly used dipsticks for the detection of albuminuria.

\begin{tabular}{lcc}
\hline & Micral-test & Multistix 10 SG, Bayer [45] \\
\hline Type & Semiquantities & Qualitative \\
Level of detection & $20 \mathrm{mg} / \mathrm{L}$ & $200 \mathrm{mg} / \mathrm{L}$ \\
$\begin{array}{l}\text { Level of } 100 \% \\
\text { specificity }\end{array}$ & $35 \mathrm{mg} / \mathrm{L}$ & - \\
$\begin{array}{l}\text { Negative predictive } \\
\text { value }\end{array}$ & $88 \%(20 \mathrm{mg} / \mathrm{L})$ & $73.7 \%(200 \mathrm{mg} / \mathrm{L})$ \\
Time for reading & $1 \mathrm{mn}$ & $1 \mathrm{mn}$ \\
$\begin{array}{l}\text { Cost } \\
\text { Efficacy of treatment } \\
\text { (IEC) at screening }\end{array}$ & ++ & + \\
\hline
\end{tabular}

results $[32,34]$. Taking into consideration accuracy and cost, the measurement of the UAC in a random urine specimen, having $15 \mathrm{mg} / \mathrm{L}$ as the cut-off point for diagnosis, or the UACR on first morning micturition was considered by other authors as the best choice for MA screening patients with diabetes $[36,41]$. Several advantages of MT have been described such as the economic benefit [42], the rapidity of the test (total time of 3 minutes), and its validity and reliability as a screening method for albuminuria on a single urine sample. It does not require 24-hour urine collection, feasible on a morning urine sample and especially adequate in the elderly $[9,32,33]$. We propose the algorithm (Figure 2) for screening ND.

\section{Conclusion}

Detecting MA in diabetic patients leads the family doctor to speed up the adaptation of the therapeutic goals in order to have the finest metabolic control, an improvement of health-related behaviors, and an optimal treatment of the associated risk factors. Screening for MA has to be improved in primary healthcare centers. The use of reliable, cheap, and easily semiquantitative methods such as the MT seems to be a promising strategy to achieve that purpose.

\section{Competing Interests}

The authors declare that they have no competing interests. 


\section{Acknowledgments}

The authors thank the nurse staff of the healthcare centers Stah Jabeur and C2 in Monastir, where this study was conducted, for their invaluable contribution in implementing the study. Their special thanks extend to Dr. Jebara Hassen, Headmaster of the Regional Department of the Basic Healthcare in Monastir, for his help to supply the Micral-test. This work was financially supported by research committees in Monastir University.

\section{References}

[1] A. T. Reutens, L. Prentice, and R. Atkins, "The epidemiology of diabetic kidney disease," in The Epidemiology of Diabetes Mellitus, pp. 499-518, John Wiley \& Sons, 2nd edition, 2008.

[2] H. Préneuf, "Néphropathies diabétiques," EMC-Nephrologie, vol. 1, no. 1, pp. 1-16, 2011.

[3] T. Ninomiya, V. Perkovic, B. E. De Galan et al., "Albuminuria and kidney function independently predict cardiovascular and renal outcomes in diabetes," Journal of the American Society of Nephrology, vol. 20, no. 8, pp. 1813-1821, 2009.

[4] L. H. Opie and H.-H. Parving, "Diabetic nephropathy: can renoprotection be extrapolated to cardiovascular protection?" Circulation, vol. 106, no. 6, pp. 643-645, 2002.

[5] N. S. Anavekar and M. A. Pfeffer, "Cardiovascular risk in chronic kidney disease," Kidney International, vol. 92, pp. S11S15, 2004.

[6] P. C. W. Van Dijk, K. J. Jager, B. Stengel, C. Grönhagen-Riska, T. G. Feest, and J. D. Briggs, "Renal replacement therapy for diabetic end-stage renal disease: data from 10 registries in Europe (1991-2000)," Kidney International, vol. 67, no. 4, pp. 1489-1499, 2005.

[7] G. Pylypchuk and E. Beaubien, "Diabetic nephropathy. Prevention and early referral," Canadian Family Physician, vol. 46, pp. 636-642, 2000.

[8] E. Ritz, "Diabetic nephropathy," Saudi Journal of Kidney Diseases and Transplantation, vol. 17, no. 4, pp. 481-490, 2006.

[9] L. Cortés-Sanabria, H. R. Martínez-Ramírez, J. L. Hernández, E. Rojas-Campos, J. L. Canales-Muñoz, and A. M. CuetoManzano, "Utility of the Dipstick Micraltest II in the screening of microalbuminuria of diabetes mellitus type 2 and essential hypertension," Revista de Investigación Clínica, vol. 58, p. 190, 2006.

[10] A. Szymanowicz, E. Blanc-Bernard, C. Roche, M. J. Neyron, M. Perrin, and K. Nourdine, "Evaluation du micral test en vue du dépistage de la microalbuminurie en biologie délocalisée," Immuno-Analyse et Biologie Spécialisée, vol. 23, pp. 109-115, 2008.

[11] P. Giannuzi and D. A. Wood, "Guidelines on primary prevention of cardiovascular disease," European Journal of Cardiovascular Prevention and Rehabilitation, vol. 14, pp. S1-S113, 2007.

[12] American Diabetes Association, "Standards of medical care in diabetes-2013," Diabetes Care, vol. 36, supplement 1, pp. S11S66, 2012.

[13] T. Bouattar, S. Ahid, S. Benasila et al., "The factors for progression of the diabetic nephropathy: management and evolution," Nephrologie et Therapeutique, vol. 5, no. 3, pp. 181-187, 2009.

[14] M. Marre, A. Girault, and D. Vasmant, "Prévalence de la microalbuminurie chez les diabétiques de type 2 français suivis par leur médecin généraliste," Diabète et Métabolisme, vol. 21, pp. 34-40, 1995.

[15] P. Sabouret, T. Denolle, M. Krempf, S. Om, and M. Laville, "Enquête microalb: dépistage de la microalbuminurie chez l'hypertendu diabétique de type 2 par le médecin généraliste en France métropolitaine," Archives des Maladies du Coeur et des Vaisseaux, vol. 99, pp. 712-717, 2006.

[16] A. Guerin, O. Savary, and S. Del Puppo, "Enquête mira: épidémiologie de la microalbuminurie et des comorbidités associées chez le diabétique de type 2," Archives des Maladies du Coeur et des Vaisseaux, vol. 98, pp. 783-787, 2005.

[17] L. Bendriss, A. Lebbaq, H. Jallal, S. Mrani, and A. Khatouri, "Intérêt de la microalbuminurie au sein du syndrome métabolique dans la prédiction des évènements cardiovasculaires. Étude prospective à propos de 78 cas," Annales de Cardiologie et d'Angéiologie, vol. 61, no. 1, pp. 15-19, 2012.

[18] A. Al-Adsani, "Risk factors associated with albuminuria in Kuwaiti adults with type 2 diabetes," Saudi Journal of Kidney Diseases and Transplantation, vol. 23, no. 4, pp. 860-865, 2012.

[19] U. Krairittichai, S. Potisat, A. Jongsareejit, and C. Sattaputh, "Prevalence and risk factors of diabetic nephropathy among Thai patients with type 2 diabetes mellitus," Journal of the Medical Association of Thailand, vol. 94, pp. S1-S5, 2011.

[20] K. D. Prasad and P. Rajaseker, "Study of microalbuminuria as a cardiovascular risk factor in type 2 diabetes mellitus," Asian Journal of Pharmaceutical and Clinical Research, vol. 5, pp. 4243, 2012.

[21] F. A. Rahamtalla, "Prevalence of microalbuminuria among sudanese type 2 diabetic patients at elmusbah center at ombadda-omdurman," IOSR Journal of Pharmacy, vol. 2, no. 5, pp. 51-55, 2012.

[22] H.-H. Parving, J. B. Lewis, M. Ravid, G. Remuzzi, and L. G. Hunsicker, "Prevalence and risk factors for microalbuminuria in a referred cohort of type II diabetic patients: a global perspective," Kidney International, vol. 69, no. 11, pp. 2057-2063, 2006.

[23] M. Shebl and M. Atteia, "High prevalence of MicroAlbuminuria (MA) in type 2 diabetic patients," Health Care, vol. 21, pp. 221232, 2008.

[24] F. Al-Maskari, M. El-Sadig, and E. Obineche, "Prevalence and determinants of microalbuminuria among diabetic patients in the United Arab Emirates," BMC Nephrology, vol. 9, article 1, 2008.

[25] W. Jia, X. Gao, C. Pang et al., "Prevalence and risk factors of albuminuria and chronic kidney disease in Chinese population with type 2 diabetes and impaired glucose regulation: Shanghai diabetic complications study (SHDCS)," Nephrology Dialysis Transplantation, vol. 24, no. 12, pp. 3724-3731, 2009.

[26] P. Sánchez Azcona and N. B. Quaglia, "A higher prevalence of microalbuminuria in women in a diabetes management program at a public hospital in the south of Santa Fe province," Revista Argentina de Endocrinologia y Metabolismo, vol. 48, no. 3, pp. 158-163, 2011.

[27] S. Maeda, N. Osawa, T. Hayashi, S. Tsukada, M. Kobayashi, and R. Kikkawa, "Genetic variations associated with diabetic nephropathy and type II diabetes in a Japanese population," Kidney International, vol. 72, no. 106, pp. S43-S48, 2007.

[28] A. I. Adler, R. J. Stevens, S. E. Manley, R. W. Bilous, C. A. Cull, and R. R. Holman, "Development and progression of nephropathy in type 2 diabetes: the United Kingdom Prospective Diabetes Study (UKPDS 64)," Kidney International, vol. 63, no. 1, pp. 225-232, 2003. 
[29] I. Arfa, A. Abid, S. Nouira et al., "Lack of association between the angiotensin-converting enzyme gene (I/D) polymorphism and diabetic nephropathy in Tunisian type 2 diabetic patients," Journal of the Renin-Angiotensin-Aldosterone System, vol. 9, no. 1, pp. 32-36, 2008.

[30] J. M. Zacharias, T. K. Young, N. D. Riediger, J. Roulette, and S. G. Bruce, "Prevalence, risk factors and awareness of albuminuria on a Canadian First Nation: a community-based screening study," BMC Public Health, vol. 12, article 290, 2012.

[31] P. Gæde, H. Lund-Andersen, H.-H. Parving, and O. Pedersen, "Effect of a multifactorial intervention on mortality in type 2 diabetes," The New England Journal of Medicine, vol. 358, no. 6, pp. 580-591, 2008.

[32] B. Larijani, P. Hemati, A. Javadi, M. Mahmoudi, and A. Shafaee, "Screening for Microalbuminuria in the early detection of diabetic nephropathy: a cheap and simple method," Acta Medica Iranica, vol. 40, pp. 1-2, 2002.

[33] J. P. Le Floch, M. Marre, M. Rodier, and P. H. Passa, "Interest of clinitek ${ }^{\circledR}$ microalbumin in screening for microalbuminuria: results of a multicentre study in 302 diabetic patients," Diabetes and Metabolism, vol. 27, no. 1, pp. 36-39, 2001.

[34] P. McFarlane and B. Culleton, "La néphropathie chronique en présence de diabète," Canadian Journal of Diabetes, vol. 32, pp. S139-S147, 2008.

[35] W. J. C. De Grauw, E. H. Van de Lisdonk, H. J. M. Van den Hoogen et al., "Screening for microalbuminuria in type 2 diabetic patients: the evaluation of a dipstick test in general practice," Diabetic Medicine, vol. 12, no. 8, pp. 657-663, 1995.

[36] J. Incerti, T. Zelmanovitz, J. L. Camargo, J. L. Gross, and M. J. de Azevedo, "Evaluation of tests for microalbuminuria screening in patients with diabetes," Nephrology Dialysis Transplantation, vol. 20, no. 11, pp. 2402-2407, 2005.

[37] C. E. Mogensen, G. C. Viberti, E. Peheim et al., "Multicenter evaluation of the Micral-Test II test strip, an immunologic rapid test for the detection of microalbuminuria," Diabetes Care, vol. 20, no. 11, pp. 1642-1646, 1997.

[38] C. R. Parikh, M. J. Fischer, R. Estacio, and R. W. Schrier, "Rapid microalbuminuria screening in type 2 diabetes mellitus: simplified approach with Micral test strips and specific gravity," Nephrology Dialysis Transplantation, vol. 19, pp. 1881-1885, 2004.

[39] P. A. Sarafidis, J. Riehle, Z. Bogojevic, E. Basta, A. Chugh, and G. L. Bakris, "A comparative evaluation of various methods for microalbuminuria screening," American Journal of Nephrology, vol. 28, no. 2, pp. 324-329, 2008.

[40] D. J. Webb, D. J. Newman, N. Chaturvedi, and J. H. Fuller, "The use of the Micral-Test strip to identify the presence of microalbuminuria in people with insulin dependent diabetes mellitus (IDDM) participating in the EUCLID study," Diabetes Research and Clinical Practice, vol. 31, pp. 93-102, 1996.

[41] G. Bruno, P. Cavallo-Perin, G. Bargero et al., "Prevalence and risk factors for micro-and macroalbuminuria in an Italian population-based cohort of NIDDM subjects," Diabetes Care, vol. 19, no. 1, pp. 43-47, 1996.

[42] D. Jacobs, W. DeMott, H. Grady, R. Horvat, D. Huestis, and B. Kasten, Laboratory Test Handbook, Lexi-Comp, Cleveland, Ohio, USA, 1996.

[43] N. Pasko, F. Toti, E. Zekollari, A. Strakosha, V. Kacori, and N. Thereska, "Prevalence of microalbuminuria in type 2 diabetes patients in Tirana, a preliminary multicenter study," Journal of Diabetes Mellitus, vol. 3, no. 3, pp. 145-149, 2013.

[44] H. Ben Ahmed, K. Bouzid, M. Hassine et al., "Prévalence des facteurs de risque cardiovasculaire non conventionnels chez les sujets diabétiques tunisiens," La Presse Médicale, vol. 43, no. 1, pp. e9-e16, 2014.

[45] C. Garcia, L. Bordier, P. Burnat et al., "Urinary dipsticks must not be used to detect diabetes-induced incipient nephropathy," La Presse Médicale, vol. 35, no. 7-8, pp. 1117-1121, 2006. 


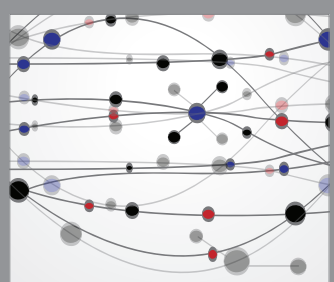

The Scientific World Journal
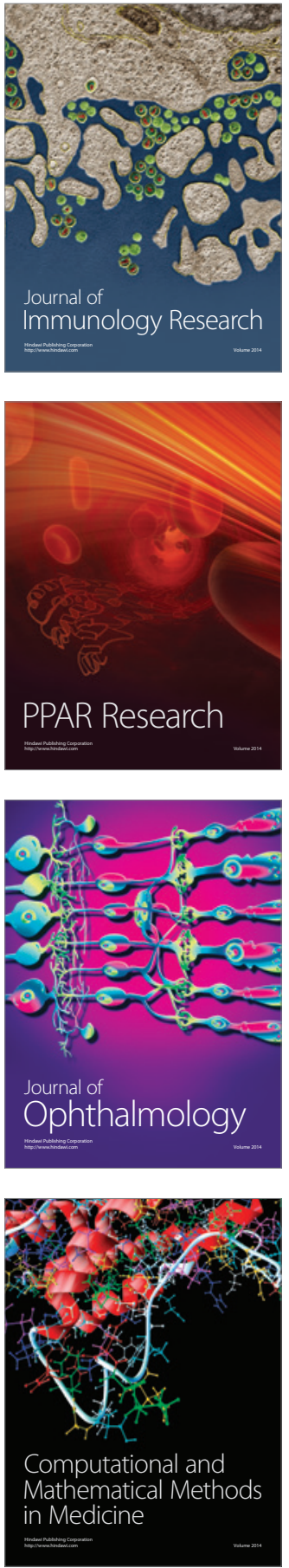

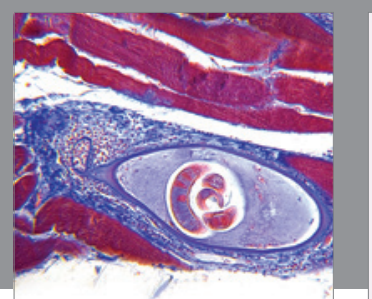

Gastroenterology Research and Practice

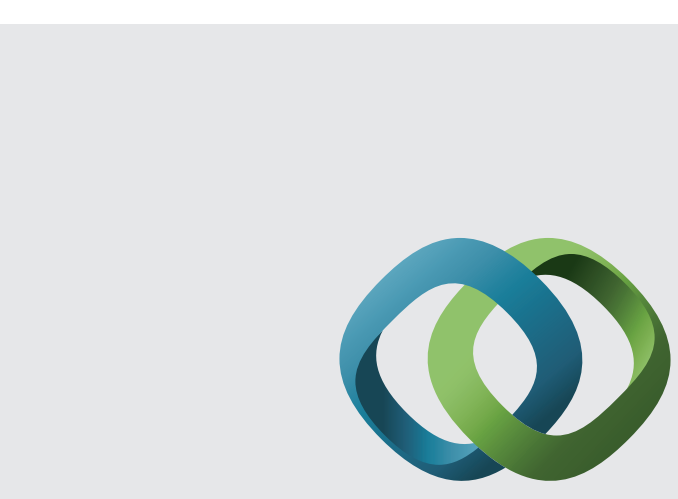

\section{Hindawi}

Submit your manuscripts at

http://www.hindawi.com
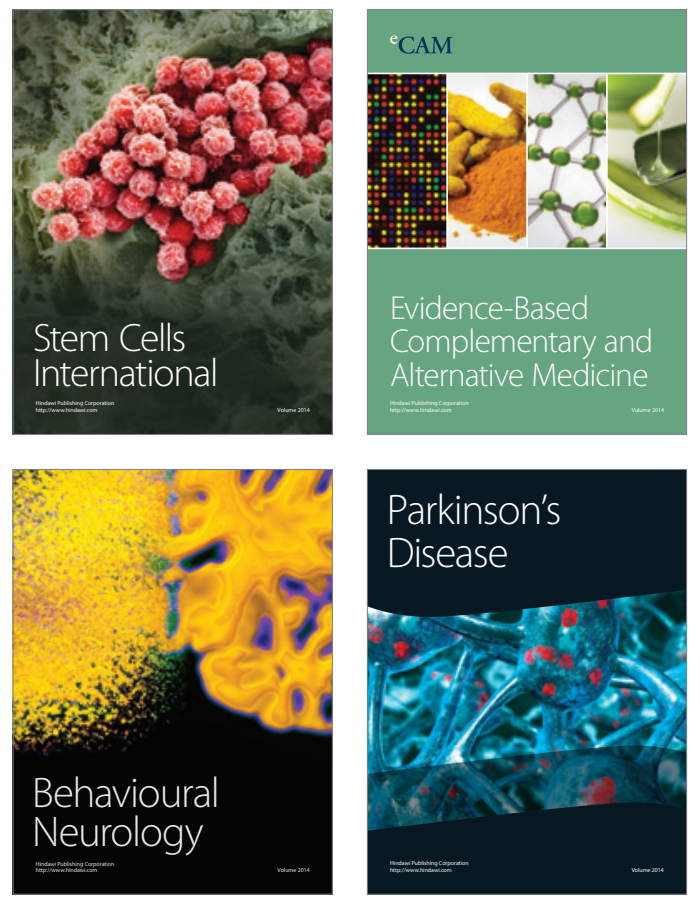
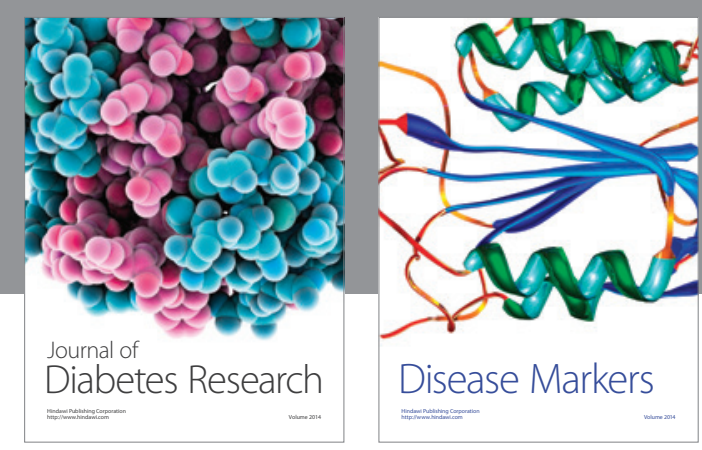

Disease Markers
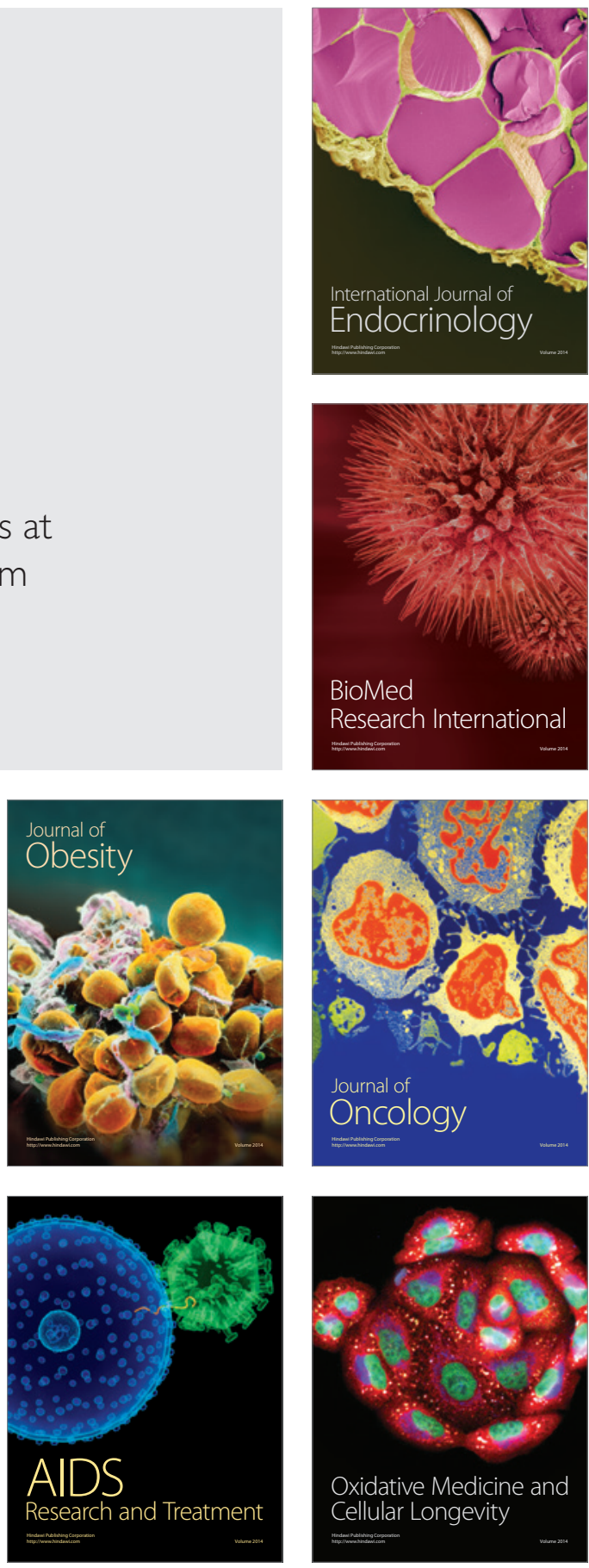